ISSN 2598-3180 (Online)

JOURNAL OF MIDWIFERY

Re se archand Practice

\title{
Factors Associated With The Assessment Of Maternal Participant Satisfaction Of BPJS Health In The Working Area Of Public Health Center Lubuk Buaya Padang City 2017
}

\author{
Rahmayani Afrah, Defrin, Ayu Nurdiyan \\ Bachelor Of Midwifery Program FK-UNAND, Jln Niaga No.56 Padang City, 25127, Indonesia \\ Bachelor Of Midwifery Program FK-UNAND, Jln Niaga No.56 Padang City, 25127, Indonesia \\ Bachelor Of Midwifery Program FK-UNAND, Jln Niaga No.56 Padang City, 25127, Indonesia
}

\begin{tabular}{l}
\hline SUBMISSION TRACK \\
\hline Recieved: Mei 172017 \\
Final Revision: Agustus 18, 2017 \\
Available Online: Nopember 24, 2017 \\
KEYWORD
\end{tabular}

Assessment, BPJS, previous service.

KORESPONDENSI

Phone: 075120120

E-mail: rahmayaniafrah@yahoo.co.id

\section{A B S T R A C T}

Satisfaction is someone's level of approval when comparing perceived performance or result with his or her expectation. Satisfaction assessment aims to determine the quality of a service. Based on the preliminary survey, Lubuk Buaya Public Health Center has the largest number of BPJS Health participants in Padang, but the scope of maternity gets decreased. This study seeks to investigate the relevant factors that influence the satisfaction assessment of BPJS Health participants with maternity services in the working area of Lubuk Buaya Public Health Center in Padang in 2017.

This study was quantitative research with cross sectional design and was conducted in the working area of Lubuk Buaya Public Health Center from May to July 2017. Sample of this research were 75 puerperal mothers. Data were collected by using questionnaire. Data analysis was performed by using univariate and bivariate.

The results showed that there are 26 dissatisfied respondents $(34.7 \%)$ and 49 satisfied respondents $(65.3 \%)$. Based on the analysis of maternal satisfaction level, the satisfaction of BPJS Health participants in the working area of Lubuk Buaya Public Health Center was 76.13\%. The result of bivariate analysis showed that there was no correlation between participants' age ( $\mathrm{p}=0,198)$, membership of BPJS Health $(\mathrm{p}=0,961)$, and previous service $(p=0,673)$, but there was a correlation between education $(\mathrm{p}=0,001)$, employment $(\mathrm{p}=0,001)$ and parity $(p=0,035)$ with assessment of BPJS Health participants in working area of Lubuk Buaya Public Health Center in Padang in 2017.

There was a correlation between education, employment, and parity with the assessment of BPJS Health participants who got maternity services. Therefore, health workers have to do evaluation about the maternity services in order to improve maternity satisfaction of BPJS Health participants. 


\section{INTRODUCTION}

Health is a Human Right, everyone has equal rights in obtaining safe, quality and affordable health services, and vice versa everyone has an obligation to participate in social health insurance. In 2004 Law number 40 on the National Social Security System (SJSN) was enacted, the Act mandates that social security is compulsory for all residents including the National Health Insurance (JKN). The National Health Insurance is a guarantee of health protection to the participants in order to fulfill their basic health needs, the body that has a role in running it is the Social Security Administering Board (BPJS) (Law No. 36/2009) Law No. 40/2004, Permenkes RI, Number 28 , 2014).

The JKN program begins on January 1, 2014. The current implementation of JKN is in the medium term (2010-2025), the things that must be prepared at this stage are the adjustment of the guarantee program on fee terms, capacity building, membership expansion and service quality improvement. At this stage JKN service quality is expected to increase, so that later in year 2025 Indonesia already has a healthy health insurance and Universal Health Coverage can be done (Sulastomo, 2008).

The World Health Organization (WHO) in Thabrany (2015) sets out three dimensions in determining the perfection of health insurance. The first dimension is the number of population, a health system is said to be good if $100 \%$ of the population get health insurance, the second dimension is the quality of service, the quality of service each community has different assessments, in accordance with services and information received by the community, and the third dimension is the cost dimension. To achieve the perfection of the health insurance system required a continuous evaluation so that it can be known the development of the system. According to Thabrany (2014), one of Indonesia's current health insurance problems is its slow development when compared to ASEAN countries, one of the causes of the delay in the development of JKN is the quality of service that is still lacking and not satisfactory.

Based on data sources BPJS Health (2017) and Health Office of West Sumatra (2016), the number of participants BPJS Health is 175.739.499 people and the number of participants BPJS Health in West Sumatra is $3,500,787$ people $(67.37 \%)$. The city of Padang has the largest number of BPJS Health participants (694,956 inhabitants) from 19 districts / cities in West Sumatera Province, followed by Agam Regency (368,089 people) and Padang Pariaman District (234,133 inhabitants).

Normal labor care is one of the services covered by BPJS Health at first-rate health facilities. Every normal delivery service is expected to be assisted at a first-rate health facility. Based on Indonesia Health Profile 2015, coverage of delivery assistance by health personnel from 2013 to 2015 has decreased. In 2013 , the coverage of labor of health workers was $90.88 \%$, decreased in 2014 to $88.68 \%$, and in 2015 to $88.55 \%$. The low coverage of delivery assistance by health personnel is one of the main causes of the high maternal mortality rate (MMR) in Indonesia (305 per 100,000), with health BPJS there should be an increase in community efforts to utilize health services that are expected to reduce MMR in Indonesia. The question is the quality of delivery services delivered, the quality of a service can be seen from the level of satisfaction of the service recipient. A service is said to be qualified and qualified if the recipient has a high level of satisfaction (Ministry of Health, 2016, Pohan, 2006).

Satisfaction is the feeling of a person compared between expectations with results or performance. According to Parasuraman (1988) in Bustami (2011: 5), there are five dimensions in determining the satisfaction of a service, namely tangiable, reability, responsiveness, assurances and empathy (emphaty). Satisfaction can be measured by comparison of expectations and reality, if expectations are lower or equal to reality, patients are satisfied with service, but if expectations are higher than reality they are less satisfied with health services (Pohan, 2006).

The assessment of patient satisfaction with a service is strongly influenced by the views of the patient itself, because each patient has different backgrounds, education, knowledge, work, experience, environment and interests. When viewed from the viewpoint of the patient as the recipient of the service, the patient will assess a quality service if it has fulfilled its needs and services received politely, timely, polite, responsive, and effectively solve the patient's problem. The view of the patient as the recipient of the service greatly affects the continuity of the health service, if the patient considers the 
services received can not meet their needs and cause disappointment, then for the next patient will not come to the health service. This will affect the health and welfare of the community (Satrianegara and Saleha, 2009).

Based on research conducted by Maulana (2012), about the evaluation of pregnant woman's satisfaction toward ANC service quality in Jambi City, that satisfaction level is significantly influenced by mother's characteristic $(\mathrm{P}<0,05)$, but not significant to education and mother's age (P> 0.05). In contrast to Hikma, Kartasurya, and Mawarni (2014) research on the relationship between the quality of normal delivery service by the village midwife and maternity satisfaction in Luwu District, South Sulawesi, the result of the research is the satisfaction of delivery service significantly influenced by maternal education, maternal satisfaction level middle and upper educational backgrounds were higher than that of middle-educated mothers $(66.7 \%, 20 \%)$ (P $<0.05$ ), but the satisfaction level was not significant for age and mothers' occupation. In a study conducted by Sari (2015) on differences in patient satisfaction rates of BPJS with general patients at RSUD DR.Soedirman Mangun Sumarso Wonogiri, there was a significant difference in satisfaction rates, based on this study, general patients had better satisfaction rates, with a margin of $39,51 \%$ compared to BPJS patients.

Puskesmas is one of the primary health care facilities responsible for organizing health development. The maternal and child health effort is also one of compulsory efforts for puskesmas in order to reduce maternal mortality and infant mortality rate, from 22 health centers in Padang, Lubuk Buaya Health Center is health center with the most health BPJS participant is 36,485 people, followed by Puskesmas Andalas $(34,485$ inhabitants) and Pauh Puskesmas (27.115 inhabitants). Although most health BPJS participants in Padang City are Lubuk Buaya Community Health Centers, but the number of births assisted by health personnel has decreased from the previous year of 2,048 people (100\%) in 2015 , to 1,369 people $(84.5 \%$ ) in 2016 and this figure is far below the target coverage of delivery by health personnel (95\%). Based on a preliminary survey of 10 mothers in the work area of Lubuk Buaya Health Center, 6 mothers said they were satisfied with the delivery service and 4 mothers said they were not satisfied (Thrihono, 2005 BPJS Health, 2016, Padang City
Health Office 2016, Lubuk Buaya Community Health Center, 2017).

Based on the information that has been described, the authors are interested to conduct research on the factors related to the assessment of maternity satisfaction of BPJS participants in the work area of Health Center of Lubuk Buaya Padang City in 2017.

\section{METHODS}

This research is a type of analytic research with Cross sectional approach. Sample criteria in this study include Inclusion Criteria: willing to be a respondent, BPJS Health participants, normal maternal vaginal, in the puerperium. Exclusion Criteria: experiencing obstacles in communicating, can read write, maternity with complications. The samples in this study were mothers who met the inclusion and exclusion criteria as well as mothers who could be encountered when the researcher made a home visit. This research was conducted in the Work Area of Lubuk Buaya Community Health Center, Koto Tangah Sub-district, Padang City. The timing of the study in November 2016 September 2017

The purpose of this study was to determine the factors associated with the assessment of maternity satisfaction of BPJS health participants in the working area of Lubuk Buaya Padang Health Center in 2017

\section{RESULT}

Characteristics of Respondents

Table 1. Characteristics of respondents in the Working Area of Lubuk Buaya Community Health Center, Padang City Year 2017.

\begin{tabular}{llcc}
\hline No & \multicolumn{1}{c}{ Characteristic } & $\begin{array}{c}\mathbf{f} \\
(\mathbf{n = 7 5 )}\end{array}$ & $\mathbf{( \% )}$ \\
\hline 1. & Age & 0 & $0 \%$ \\
& $<20$ years & 62 & $82,7 \%$ \\
& $>$ 20 - 35 years & 13 & $17,3 \%$ \\
\hline > 35 years & & \\
\hline $2 . \quad$ Education & 5 & $6,7 \%$ \\
& Primary school & 11 & $14,7 \%$ \\
& Junior high school & 40 & $53,3 \%$ \\
& Senior high school & 19 & $25,3 \%$ \\
\hline Diploma and above & Occupation & 33 & $44 \%$ \\
& House wife & 22 & $29,3 \%$ \\
& Entrepreneurs & 17 & $22,7 \%$ \\
& Self Employees & 3 & $4 \%$ \\
\hline
\end{tabular}


Based on Table 1 above shows that most respondents in the age group $>20-35$ years is $82.7 \%$. Most recent education respondents at the level of high school / equivalent is $53.3 \%$. Most of the respondents were self-employed (29.3\%), private employees $(22.7 \%)$, and Govermental Employee (4\%).

\section{Age}

Table 2. Distribution of Maternal Frequency Age of Participants of BPJS Health

\begin{tabular}{lcc}
\hline Age & $\mathbf{f}(\mathbf{n}=\mathbf{7 5})$ & $\mathbf{( \% )}$ \\
\hline At risk & 13 & 17,3 \\
Not at Risk & 62 & 82,7 \\
\hline
\end{tabular}

Based on research most of maternal mother is at age reproductive / not risk, that is at age> $20-35$ years $(82,7 \%)$. According to Srivastava (2015), At the age of 20-35 years the mother will tend to be more selective in assessing the service because it still feels that the service it receives is very important.

Table 3. Analisis of Age Relation with Satisfaction

\begin{tabular}{|c|c|c|c|c|c|c|c|c|}
\hline & \multicolumn{4}{|c|}{ Satisfaction } & & & & \\
\hline \multirow[t]{2}{*}{ Age } & \multicolumn{2}{|c|}{$\begin{array}{c}\text { Not } \\
\text { Satisfied }\end{array}$} & \multicolumn{2}{|c|}{ Satisfied } & \multicolumn{2}{|c|}{ Total } & \multirow{2}{*}{$\begin{array}{l}\text { POR } \\
(95 \% \mathrm{CI}) \\
\end{array}$} & \multirow[t]{2}{*}{ P-value } \\
\hline & f & $\%$ & f & $\%$ & $f$ & $\%$ & & \\
\hline At risk & 2 & 15,4 & 11 & 85,6 & 13 & 100 & 0,288 & \\
\hline Not at Risk & 24 & 38,7 & 38 & 61,3 & 62 & 100 & $(0,059-1,413)$ & 0,198 \\
\hline Jumlah & 26 & 34,7 & 49 & 65,3 & 75 & 100 & & \\
\hline
\end{tabular}

Based on table 3, 11 (85.6\%) of respondents at risk are satisfied with the service. While among women who were not at risk, there were $38(61.3 \%)$ mothers were satisfied with the service. Based on statistical test, p-value> 0,05 (p $=0,198)$ can be concluded that there is no correlation between age and maternal satisfaction assessment of BPJS Health participant in Lubuk Buaya Community Health Center 2017.

Farianita (2016) stated that young age $(<35$ years) has a relatively lower satisfaction level than old age $>35$ years old, age will affect the knowledge possessed by someone who later can influence decision making for health status. Young people are more sensitive and open to information and more daring to express their dissatisfaction while older people tend to accept, less informative and more resigned to the services they get.

\section{Education}

Table 4. Distribution of Maternal Education Frequency of Participants of BPJS Health

\begin{tabular}{ccc}
\hline Education & $\mathbf{f}(\mathbf{n}=\mathbf{7 5})$ & $\mathbf{( \% )}$ \\
\hline Low & 16 & 21,3 \\
High & 59 & 78,7 \\
\hline
\end{tabular}

Based on table 4, most respondents are highly educated (78.7\%). According to Notoatmodjo (2010), the level of education is a significant predisposing factor in influencing one's views, where educational background is a very fundamental factor to motivate a person to health behavior.

Table 5. Analysis of Education Relationship with Satisfaction

\begin{tabular}{cccccccc}
\hline & \multicolumn{3}{c}{ Satisfaction } & \multicolumn{2}{c}{} \\
\hline Education & \multicolumn{2}{c}{ Not Satisfied } & \multicolumn{2}{c}{ Satisfied } & \multicolumn{2}{c}{ Total } \\
\cline { 2 - 7 } & f & $\%$ & F & $\%$ & f & $\%$ \\
\hline Rendah & 0 & 0 & 16 & 100 & 16 & 100 \\
\hline Tinggi & 26 & 44,1 & 33 & 55,9 & 59 & 100 \\
Total & $\mathbf{2 6}$ & $\mathbf{3 4 , 7}$ & $\mathbf{4 9}$ & $\mathbf{6 5 , 3}$ & $\mathbf{7 5}$ & $\mathbf{1 0 0}$ \\
\hline
\end{tabular}

Based on table 5, obtained $16(100 \%)$ respondents with low education, was satisfied with the delivery service received. While among the respondents who are highly educated, there are $33(55.9 \%)$ of respondents who are satisfied with the delivery service it receives. From the results of the study, there is a trend between education and maternal satisfaction assessment of participants BPJS Health, low-educated mothers are more likely to feel satisfied with the service received.

According to Imami (2016) People with low education are more satisfied with service than with high education. Highly educated people tend to be dissatisfied because their knowledge demands better service. Highly educated people think more critically, more informative, and expect more so they tend not to be satisfied with ministries that are less suited to their expectations, whereas those with lesser education tend to be more accepting and understand what has been given to them. Education will change perceptions of health services, highly educated people have higher expectations than those with low education (Srivastava, et al, 2015). 
Occupation

\begin{tabular}{cccc} 
Table & $\begin{array}{c}\text { 6.Distribution } \\
\text { Maternity } \\
\text { Participants of BPJS Health }\end{array}$ & $\begin{array}{c}\text { of } \\
\text { Occupation }\end{array}$ & $\begin{array}{c}\text { of } \\
\text { of }\end{array}$ \\
\hline \multicolumn{2}{c}{ Occupation } & f (n=75) & $(\%)$ \\
\hline Does not work & 33 & 44 \\
Working & 42 & 56 \\
\hline
\end{tabular}

Based on table 6, most respondents work $(56 \%)$. A person who does not work usually has lower expectations of a service, so it will tend to have a better satisfaction assessment (Srivastava, et al, 2015).

Table 7.Analisis of Accupation Relations with Satisfaction

\begin{tabular}{c|c|c|c|c|c|c}
\hline \multirow{2}{*}{ Occupation } & \multicolumn{3}{c}{ Satisfaction } & \multicolumn{2}{c}{ Not } & \multicolumn{2}{c}{ Satisfied } & \multicolumn{2}{c}{ Total } \\
& Satisfied & \multicolumn{2}{c}{} & \multicolumn{2}{c}{} \\
\cline { 2 - 8 } & f & $\mathbf{\%}$ & $\mathbf{f}$ & $\mathbf{\%}$ & $\mathbf{f}$ & $\mathbf{\%}$ \\
\hline Does not work & 4 & 12,1 & 29 & 87,9 & 33 & 100 \\
work & 22 & 52,4 & 20 & 47,6 & 42 & 100 \\
Total & $\mathbf{2 6}$ & $\mathbf{3 4 , 7}$ & $\mathbf{4 9}$ & $\mathbf{6 5 , 3}$ & $\mathbf{7 5}$ & $\mathbf{1 0 0}$ \\
\hline
\end{tabular}

According to Table 7, 29 (87.9\%) of the respondents did not work were satisfied with the services they received. While among the respondents who work, there are $20(47.6 \%)$ of respondents feel satisfied with the service. Based on the statistical test, $\mathrm{p}$-value $<0,05(\mathrm{p}=0,00)$ can be concluded that there is a significant correlation between the work and the maternal satisfaction assessment of participant of BPJS Kesehatan at Lubuk Buaya Community Health Center 2017.

People who have better employment status then higher levels of satisfaction, people who work tend to have higher expectations than people who do not work for health services, someone who has a job and a better job is likely to have a higher level of satisfaction to demand that service better than someone who does not have a job (Al Ahmar, 2014).

\section{Parity}

\section{Table 8. Distribution of Maternal Frequency Parity Participants of BPJS Health Participants}

\begin{tabular}{ccc}
\hline Parity & $\mathbf{f}(\mathbf{n}=\mathbf{7 5})$ & $\mathbf{( \% )}$ \\
\hline Primipara & 28 & 37,3 \\
Multipara & 47 & 62,7 \\
\hline
\end{tabular}

Based on table 8 , most of the respondents in this study were multiparas $(62.7 \%)$. The results of this study are in line with Maulana (2012) study, that satisfied respondents more on primiparous mothers (51.4\%) than multiparas (27.3\%). In contrast to Srivastava's (2015) study, the results of his research of multiparous mothers tend to be more satisfied with services than primiparous mothers.

\section{Table 9. Parity Analysis with Satisfaction}

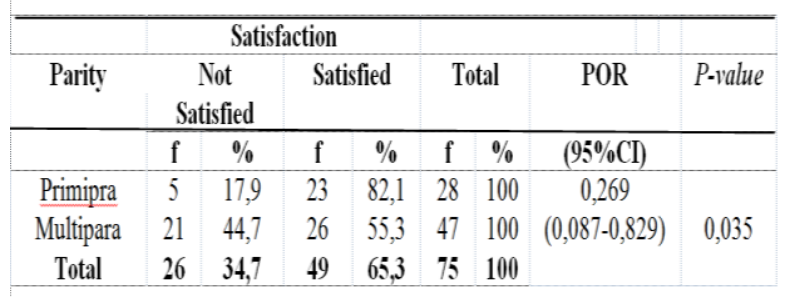

Based on table 9, 23 (82.1\%) of primiparous respondents were satisfied with the services provided. Whereas between multiparent respondents, there were $26(55.3 \%)$ of respondents who were satisfied with the delivery service they received. Based on statistical test, $\mathrm{p}$ value $<0,05(p=0,024)$ can be concluded that there is a significant correlation between parity with maternity satisfaction assessment of BPJS Health participant in Lubuk Buaya Community Health Center 2017. This research is supported by Maulana (2012), that there is a significant relationship between parity and satisfaction assessment. But unlike Oikawa's research, et al (2014), which concluded that there is no significant relationship between parity and patient satisfaction.

Based on the research there is a significant relationship between parity with maternity satisfaction assessment. The most satisfied respondents were primiparous respondents. This means that multiparous patients have higher rates of expectation than primiparas, which may be due to earlier received better delivery services. Healthcare facilities can improve services and consider services provided primarily in multiparous patients. Multiparous mothers have a 0.269 chance of being dissatisfied with delivery services compared to primiparous mothers. 


\section{BPJS Health Participation}

Table 10.Distribution of Frequency of Participation of BPJS Maternal Health Participants of BPJS Health

\begin{tabular}{ccc}
\hline $\begin{array}{c}\text { BPJS Health } \\
\text { Participation }\end{array}$ & $\mathbf{f}(\mathbf{n}=\mathbf{7 5})$ & $\mathbf{( \% )}$ \\
\hline PBI & 19 & 25,3 \\
Non PBI & 56 & 74,7 \\
\hline
\end{tabular}

Based on table 10, Judging from the participation of BPJS Kesehatan most of the respondents are independent participants (74.7\%). In contrast to the results of Farianita's (2016) study, more satisfied mothers in non-PBI participants $(67.7 \%)$ than PBI $(15.6 \%)$.

Table 11. Analysis of BPJS Health participation with Satisfaction

\begin{tabular}{|c|c|c|c|c|c|c|}
\hline & & \multicolumn{2}{|c|}{ Satisfaction } & \multirow[b]{2}{*}{ Total } & \multirow[b]{2}{*}{ POR } & \multirow[b]{2}{*}{ Prvalue } \\
\hline \multirow[t]{2}{*}{$\begin{array}{l}\text { BPJS Health } \\
\text { participation }\end{array}$} & $\begin{array}{r}\mathrm{N} \\
\text { Sati }\end{array}$ & $\begin{array}{l}\text { ot } \\
\text { fied }\end{array}$ & Satisfied & & & \\
\hline & $\mathrm{f}$ & $\%$ & f $\%$ & f $\%$ & $(95 \%$ CI $)$ & \\
\hline PBI & 6 & 31,6 & $\begin{array}{ll}13 & 68,4 \\
\end{array}$ & $\begin{array}{ll}19 & 100\end{array}$ & 0,831 & \\
\hline Non PBI & 20 & 35,7 & $\begin{array}{ll}36 & 64,3\end{array}$ & $\begin{array}{ll}56 & 100\end{array}$ & $(0,273-2,524)$ & 0,961 \\
\hline Total & 26 & 34,7 & 49 $\quad 65,3$ & $\begin{array}{ll}75 & 100\end{array}$ & & \\
\hline
\end{tabular}

Based on table 11, it was found that there were 13 respondents (68.4\%) Recipients of the Contribution Aid (PBI) were satisfied with the services provided. Meanwhile, among non PBI participants there were $36(64.3 \%)$ of respondents were satisfied with the delivery service provided. Based on the statistical test, $\mathrm{p}$ value $>0,05(\mathrm{p}=0,788)$ can be concluded that there is no relationship between BPJS Health Participation with maternity satisfaction assessment of participant of BPJS Kesehatan at Lubuk Buaya Community Health Center 2017. The result of this research is supported by Farianita ( 2016), there is no relationship between the participation of BPJS Health with Satisfaction Assessment and Oikawa research, et al (2014) that there is no significant relationship at every level of health service financing.

There is a difference in satisfaction between PBI and non PBI because the insured is more satisfied and this is because they only accept the services given to them, the insurer is not satisfied than the insured and this is because the insurer has the obligation to pay and tend to demand better service. Affordable care is a significant determinant of maternal satisfaction. The availability of free services increases service satisfaction (Srivastava, et al, 2010).

Based on the study there is no relationship between BPJS Health membership with maternity satisfaction assessment. In this case, the health facility should provide a uniform service to each group, since there is no relationship between service financing and satisfaction assessment.

\section{Previous Service}

Table 12.Frequency Distribution of Past Service of Maternity Mothers of BPJS Health Participants

\begin{tabular}{ccc}
\hline Previous service & $\mathbf{f}(\mathbf{n}=\mathbf{7 5})$ & $\mathbf{( \% )}$ \\
\hline Goverment & 54 & 72 \\
Private & 21 & 28 \\
\hline
\end{tabular}

Based on table 12, most respondents previously received services from governmentowned services ie Puskesmas (72\%).

Table 13. Analysis of previous health services Employment with Satisfaction

\begin{tabular}{|c|c|c|c|c|c|c|c|c|}
\hline \multirow{4}{*}{$\begin{array}{l}\text { Previous } \\
\text { Medical } \\
\text { Services }\end{array}$} & \multicolumn{4}{|c|}{ Satisfaction } & & & & \\
\hline & \multirow{2}{*}{\multicolumn{2}{|c|}{$\begin{array}{l}\text { Not } \\
\text { Satisfied }\end{array}$}} & \multirow{2}{*}{\multicolumn{2}{|c|}{ Satisfied }} & \multicolumn{2}{|c|}{ Total } & \multirow[t]{2}{*}{ P0R } & \multirow[t]{2}{*}{ P-value } \\
\hline & & & & & & & & \\
\hline & f & $\%$ & f & $\%$ & f & $\%$ & $(95 \% \mathrm{Cl})$ & \\
\hline Goverment & 20 & 37,0 & 34 & 63,0 & 54 & 100 & 1,471 & \\
\hline Private & 6 & 28,6 & 15 & 71,4 & 21 & 100 & $(0,491-4,401)$ & 0,673 \\
\hline Total & 26 & 34,7 & 49 & 65,3 & 75 & 100 & & \\
\hline
\end{tabular}

Based on table 13, it was found that 34 $(63.0 \%)$ of respondents previously received services in government-owned health services were satisfied with the services provided. Whereas among respondents who previously received services in private health facilities, there are $15(71.4 \%)$ of respondents are satisfied with the delivery service received. Based on the statistical test, $\mathrm{p}$-value $>0,05(\mathrm{p}=0,594)$ can be concluded that there is no relationship between the previous service with the assessment of maternal satisfaction of participant of BPJS Kesehatan at Lubuk Buaya Community Health Center 2017.

Previous health care experience affects the satisfaction of the service to be received further. If a person has previously received an optimal and hopeful service and then obtaining services 
that are not as expected for the future, it will further increase patient dissatisfaction with the service. However, if a person does not have a comparison with the previous service or received services are assessed equally then it will not affect patient satisfaction (Srivastava, et al, 2015).

Based on the study there is no relationship between the previous service with maternity satisfaction assessment. This means that the quality of health care received by patients is generally the same. Patients consider both private and government services to have the same quality of care. The satisfaction experienced by the patient is related to the results of the services provided by the health worker. Patients as consumers will feel satisfied if given good service and treated well, and get ease in service.

\section{Maternity Satisfaction Assessment Participants BPJS Health}

Table 14. Frequency Distribution of Maternity Satisfaction Assessment Participants of BPJS Health in the Work Area of Lubuk Buaya Community Health Center, Padang City 2017.

\begin{tabular}{ccc}
\hline Level of Satisfaction & $\mathbf{f}(\mathbf{n}=\mathbf{7 5})$ & $\mathbf{( \% )}$ \\
\hline Not satisfied & 26 & 34,7 \\
Satisfied & 49 & 65,3 \\
\hline
\end{tabular}

Based on table 14, respondents categorized not satisfied as much as 26 respondents (34.7\%) and satisfied as many as 49 respondents $(65.3 \%)$. Based on the analysis of maternal satisfaction rate of BPJS Health participants in the Work Area of Lubuk Buaya Community Health Center, the satisfaction level was $76.13 \%$. This shows that maternal satisfaction assessment is good enough.

The results are assessed based on 5 dimensions, namely reliability, responsiveness, assurance, empathy, tangible. Much of the dimension of satisfaction has already shown good suitability between hope and reality. Based on the questionnaire analysis, there is a difference in the value of conformity between maternal mothers in Puskesmas with mothers at the BPM. Maternal mothers in Puskesmas, the highest value of compliance is the dimension of responsiveness, meaning maternal mothers assess the willingness of the staff to help patients and provide responsive service is quite satisfactory.
While the lowest value is in tangible dimension means that existing physical facilities such as equipment, equipment and health facilities are still considered less satisfactory for the respondents. Unlike the maternal mothers in $\mathrm{BPM}$, the highest conformity score is in the empathy dimension, which means that the personal attention given by the existing health workers is quite satisfactory. While the lowest value of conformity is on the dimension of assurances, which means that the mother is still less confident with the capability of the knowledge of the health personnel.

Patient satisfaction is an important component in health services, a service is said to be quality if the service provided can satisfy the patient. Patient satisfaction is needed in improving the quality of health services, dissatisfaction occurs because of the gap between patient expectation and perceived service performance (Pohan, 2006). Patients will be satisfied with the service if the service performance is equal to or exceeded expectations. Feelings of dissatisfaction arise in patients who perceive the performance of health services obtained do not match expectations (Pohan, 2006).

Based on the research conducted it is known that more half of patients have felt satisfied with the delivery service in the working area of Lubuk Buaya Community Health Center. So to maintain this satisfaction needs cooperation from various parties. If the health service can lead to patient satisfaction, the patient will choose to deliver to the facility, as the patient is a social being who will always seek health services at a health facility that can meet her expectations.

A review by Y Yulizawati, D Iryani, AA Insani, A Nurdiyan stated that it is important to prepare many strategies to achieve UHC targer. If current condition stay static, the regulation that formed by government will not delivered throughly. The writer recommendate that there is a necessary to make a management system to optimalize of Midwives's role. But also there is also a necessary to increase participation and role of every stakeholders that involved in this matter (Y Yulizawati, D Iryani, AA Insani, A Nurdiyan ,2016).

Acknowledgments are given to the S1 Program of Midwifery Faculty of Medicine Andalas University who always provide support and encouragement in every research activity undertaken. 


\section{REFERENCES}

Al Ahmar, E., S. Tarraf. Assessment of the Socio-Demographic Factors Associated with the Satisfaction Related to the Childbirth Experience. Obstetrics and Gynecology. Scientific Research. Lebanon. 2014

Amdemichael, R., M, Tafa, H, Fedaku. Maternal Satisfaction with the Delivery Services in Assela Hospital, Arsi Zone, Oromia Region. Gynecology \& Obstetrics. OMICS Group. Ethiopia 4(12). 2014

Badan Penelitian dan Pengembangan Kesehatan. Laporan Hasil Riset Kesehatan Dasar (RISKESDAS) 2010. Jakarta : Depkes RI. 2010

Bustami. Penjaminan Mutu Pelayanan Kesehatan dan akseptabilitasnya. Jakarta : Erlangga, 2011

BPJS Kesehatan. Jumlah Peserta BPJS Kesehatan Terdaftar Per PPK Kota Padang. BPJS Kesehatan Cabang Padang. Padang, 2016

BPJS Kesehatan. Peserta Program JKN. BPJS Kesehatan. https://bpjs-kesehatan.go.id/bpjs/. 1 April (14.00 WIB). 2017

Dahlan, M.S. Besar Sampel dalam Penelitian. 2016 